Canadian

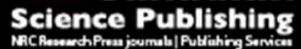

Canadian Journal of Forest Research Revue canadienne de recherche forestière

\title{
Reference Charts for Young Stands - A Quantitative Methodology for Assessing Tree Performance
}

\begin{tabular}{|r|l|}
\hline Journal: & Canadian Journal of Forest Research \\
\hline Manuscript ID & cjfr-2017-0258 \\
\hline Date Submitted by the Author: & 05-Jul-2017 \\
\hline Complete List of Authors: & $\begin{array}{l}\text { Vickers, Lance; University of Missouri, School of Natural Resources } \\
\text { Larsen, David; University of Missouri } \\
\text { Knapp, Benjamin; University of Missouri, Forestry } \\
\text { Kabrick, John; University of Missouri } \\
\text { Dey, Daniel; USDA Forest Service }\end{array}$ \\
\hline Keyword: & Height Growth, Percentile, Regeneration, Recruitment, Stand Dynamics \\
\hline $\begin{array}{r}\text { Is the invited manuscript for } \\
\text { consideration in a Special } \\
\text { Issue? : }\end{array}$ & N/A \\
\hline
\end{tabular}

\section{SCHOLARONE $^{\text {"N }}$}

Manuscripts 
Reference Charts for Young Stands - A Quantitative Methodology for Assessing Tree Performance

Lance A. Vickers, Sr. Research Specialist (Corresponding Author) University of Missouri, School of Natural Resources 203 ABNR Building Columbia, MO 65211-7280, USA

Phone: 573-882-4295; Email: lance.vickers@mizzou.edu

David R. Larsen, Professor of Quantitative Silviculture University of Missouri, School of Natural Resources 203 ABNR Building

Columbia, MO 65211-7280, USA

Phone: 573-882-4775; Email: larsendr@missouri.edu

Benjamin O. Knapp, Assistant Professor of Silviculture University of Missouri, School of Natural Resources 203 ABNR Building

Columbia, MO 65211-7280, USA

Phone: 573-882-0867; Email: knappb@missouri.edu

John M. Kabrick, Research Forester

USDA Forest Service, Northern Research Station

202 ABNR Building

Columbia, MO 65211-7260, USA

Phone: 573- 875-5341 x229; Email: jkabrick@fs.fed.us

Daniel C. Dey, Project Leader

USDA Forest Service, Northern Research Station

202 ABNR Building

Columbia, MO 65211-7260, USA

Phone: 573-875-5341 x225; Email: ddey@fs.fed.us 


\section{Abstract}

Reference charts have long been used in the medical field for quantitative clinical assessment of juvenile development by plotting distribution quantiles for a selected attribute (e.g., height) against age for specified peer populations. We propose that early stand dynamics is an area of study that could benefit from the descriptions and analyses offered by similar references for various tree measures. Reference charts provide a flexible quantitative framework that would complement traditional methods for assessing tree development. In young, mixed stands, competitive dynamics are, in part, a function of intraspecific, interspecific, and temporal variation in height development. A suite of reference charts can explicitly describe each of these, offering additional context and potentially greater insight into the complex development patterns of young trees. We illustrate this possibility and potential applications by constructing height-age reference charts for several tree species in young, mixed stands within the Missouri Ozarks.

Keywords: Height Growth, Percentile, Regeneration, Recruitment, Stand Dynamics 
1 Introduction

2 The development of forest stands following disturbance includes general stages

3 described through the study of stand dynamics. The early stages of this process are

4 complex and dynamic, including the establishment of new trees, growth rates that may

5 vary widely across species or site conditions, and widespread mortality as trees grow

6 and populations reduce. As a result, early stand development is commonly considered

7 stochastic, especially before the onset of crown closure and competition mortality.

8 Simple tools for quantitative assessment of tree and population development can

9 improve insight into the early stages of stand dynamics and help refine silvicultural

10 applications.

11 Single-cohort stands often contain mixtures of species that differ in growth rates,

12 longevity, and other life-history traits. Both the height of a tree and relative stature

13 among neighbors can influence growth and survival in developing stands (Assmann

14 1970, Oliver and Larson 1996, Weiner 1990). It is common for performance

15 assessments in these young stands to be conducted using qualitative or categorical

16 metrics, such as crown classes, with no actual measurement of tree height. Such

17 assessments are expedient and have proven useful for evaluating tree performance in

18 single-cohort stands, particularly after the onset of stem exclusion (Ward and Stephens

$191993,1994,1996)$. Though sufficient for some objectives, this level of examination may

20 be too general to capture the nuanced ecology of early stand development.

21 Early in stand development, the height profile of mixed stands may exhibit turnover in

22 species dominance (Kelty et al. 1992, Oliver and Larson 1996). Thus, an individual's 
early position among neighbors may not be indicative of long-term potential due to variation in development patterns. The relative stature of a tree in a young, mixed stand is a function of intraspecific, interspecific, and temporal variation in height development. Evaluations that do not explicitly consider each of these factors could be misleading, yet foresters lack simple tools that describe expected patterns in early height development. We suggest that a suite of quantitative references could offer improved insight into developmental patterns by providing much-needed context for measured attributes that influence growth and survival.

Reference chart methodologies have long been used in the medical field for quantitative clinical assessment of human development (Quetelet 1871, Ulijaszek et al. 1998). These charts typically include quantiles of a reference distribution plotted against age for an attribute of interest (e.g., height-age). Reference charts allow physicians to quantitatively compare the stature of an individual child at a given age to the mainstream using the distribution of statures attained by several children with similar demographics. This provides the physician valuable information to help determine if concern for irregular development is warranted (Ulijaszek et al. 1998).

We used similar techniques to develop height-age reference charts for several tree species and present them as tools for assessing early tree performance and stand development. These charts provide an explicit description of the intraspecific and interspecific variation in height development as well as the temporal dynamics of both. The objectives of this note are to 1) introduce reference charts as a complementary tool for performance assessments in young forest stands, 2) describe the general process used to develop reference charts, and 3) exhibit the potential utility of a suite of 
46 reference charts for assessing early height development. We also demonstrate how

47 reference charts can extend the inference window of stand reconstruction techniques

48 (i.e., stem analysis). We use early height-age data from single-cohort mixed stands in

49 the Missouri Ozarks to illustrate the method.

50 Methods

51 Data from two long-term studies were combined to create a time-series or

52 chronosequence of height-age development in the southeast Missouri Ozarks (ca.

$\left.53 \quad 37.2^{\circ} \mathrm{N}, 90.9^{\circ} \mathrm{W}\right)$. The region is predominately unglaciated, deeply dissected plateaus

54 composed of Ordovician and Cambrian dolomites and sandstones (Kabrick et al. 2000).

55 Average annual precipitation is $115 \mathrm{~cm}$, and average annual temperature is $13.5^{\circ} \mathrm{C}$

56 (Kabrick et al. 2008). The study sites spanned two ecological site classes: exposed

57 (aspect: $136-315^{\circ}$ ) or protected (aspect: $316-135^{\circ}$ ) backslopes (Nigh et al. 2000).

58 Average site index (Quercus velutina Lam., McQuilkin 1974) on exposed backslopes

59 was approximately $21.0 \mathrm{~m}$ (SD: $1.3 \mathrm{~m}$ ) and 22.0m (SD: 1.1m) on protected backslopes.

60 The studies monitored stand development following clearcutting or clearcutting with

61 reserves $\left(\leq 5 \mathrm{~m}^{2} \cdot \mathrm{ha}^{-1}\right.$ residual basal area). Retaining $<5 \mathrm{~m}^{2} \cdot \mathrm{ha}^{-1}$ of residual basal area

62 has little impact on sapling height growth in the study region (Vickers et al. 2014). The

63 first study included six mixed stands across the southeast Missouri Ozarks, each with

64 multiple, randomly located 0.0016-ha sample plots. The second study included 18

65 mixed stands across the southeast Missouri Ozarks, each with a single, randomly

66 located 0.02-ha plot. The two studies followed slightly different height measurement

67 protocols during the targeted first twenty years post-harvest. The first study measured 
heights of all woody stems at 2, 5, and 10 years post-harvest starting in 1973-1974. The second study started in 1996 and measured heights for woody stems $\geq 1 \mathrm{~m}$ at 3 and 8 years post-harvest and all woody stems at 16 years post-harvest. We combined the height measurements from years 2,5 , and 10 and 16 measurements to provide 4 nontruncated height-age measurements. Stems with a breast height diameter (dbh) > $6.3 \mathrm{~cm}$ at year 2 or 3 were considered residuals and removed from analyses.

Peer group selection is important for meaningful assessments of development. Just as gender and other attributes are often used in human assessments, we delineated two simple peer group categories along basic determinants of tree height: site-class groups and site-class-species groups. The site-class groups used tree height measurements for all woody stems on an ecological site class (exposed or protected backslopes) as a reference distribution. The site-class-species groups used height measurements for a species group (described below) on an ecological site class as a reference distribution.

Seven genera or sub-genera species groups were identified: 1 ) red oaks (Q. rubra L., Q. velutina Lam., Q. coccinea Münchh.), 2) white oaks (Q. alba L., Q. stellata Wangenh., Q. muehlenbergii Engelm.), 3) hickories (Carya tomentosa Sarg., C. glabra Mill., C. ovata (Mill.) K. Koch., C. texana Buckley, C. cordiformis (Wangenh.) K. Koch.), 4) sassafras (Sassafras albidum J. Presl.), 5) blackgum (Nyssa sylvatica Marsh.), 6) dogwood (Cornus florida L.), and 7) maples (Acer rubrum L., Acer saccharum Marsh.). An eighth group (other species) was comprised of species that had insufficient representation to stand alone, but were not included in previous groups including: Amelanchier arborea F. Michx., Carpinus caroliniana Walter, Celtis spp., Cercis canadensis L., Corylus americana Marshall, Crataegus spp., Diospyros virginiana L., 
91 Fraxinus spp., Gymnocladus dioicus (L.) K. Koch., Juglans nigra L., Juniperus virginiana

92 L., Morus spp., Pinus echinata Mill., Platanus occidentalis L., Prunus spp., Rhamnus caroliniana Walter, Rhus spp., Sideroxylon lanuginosum Michx., Ulmus spp., and

94 Viburnum spp. The number of trees sampled in each species group, site class, and age 95 is provided in Tables 1-3.

96 The objective of our statistical analyses was to estimate longitudinal height-age

97 quantiles for the various peer groups. Given the relatively sparse measurement intervals of our dataset compared to many human growth studies (e.g., Cole and Green 1992,

99 Wei et al. 2006), basic statistical approaches were preferred. For each peer group, we 100 101 first fit Weibull parameters (shape and scale) to the empirical height distribution at each measurement interval (i.e., ages 2, 5, 10, and 16) using the 'fitdist' function in the MASS package (Venables and Ripley 2002) of R version 3.2.2 (R Core Team 2015). Next, we derived bootstrapped estimates (2000 iterations) of the shape and scale parameters along with 95\% confidence intervals using the 'bootdist' function in the FITDISTRPLUS package (Delignette-Muller and Dutang 2015). Goodness of fit was assessed via the Anderson-Darling statistic using the 'ad.test' function in the GOFTEST package (Faraway et al. 2017) and visual inspection of CDF comparison curves. Finally, quantiles were estimated at each measurement interval using the 'qweibull' function with the bootstrapped shape and scale parameters. Linear interpolation was used to 110 plot trajectories between measurements.

111 Results 
112 The best fitting Weibull parameters in almost all cases (64 out of 72) passed the

113 Anderson-Darling test $(A D)(p$-values $>0.05)$ suggesting that the parameter estimates

114 effectively captured the empirical data distribution (Tables 1-3). In the eight cases with

$115 p$-values $\leq 0.05$, visual CDF comparisons suggested that the lack of fit was minor for

116 most (6 out of 8 ). In the remaining two cases (ages 10 and 16 for white oaks, protected

117 backslopes, Table 3) the lack of fit was somewhat more noticeable, but there was little

118 to no improvement using alternative distributions (gamma, lognormal) or removing $Q$.

119 stellata (plausibly slower-growing) from the peer group. The reference charts created

120 from the parameters in Tables 1-3 are shown in Figures 1-3. These reference charts

121 display the $10^{\text {th }}, 25^{\text {th }}, 50^{\text {th }}, 75^{\text {th }}, 90^{\text {th }}$, and $99^{\text {th }}$ quantiles, but additional quantiles are

122 readily obtained with the parameters in Tables 1-3 and basic statistical software.

123 The slope of all quantile lines tended to be positive through stand age 10 on both site

124 class reference charts (Fig. 1). Though many reference lines were quite similar on both

125 site types, by age 16 noticeable expression of within-site differences in developmental

126 dynamics appeared to be underway. Some quantiles did not increase with age while

127 others increased at varying rates. After age 10, height development was more limited on

128 exposed backslopes than protected backslopes.

129 The site-class-species charts (Figs. 2 and 3) showed considerable overlap in the height

130 distributions of many species groups, particularly early in stand development (through

131 age 5) and in the low distribution quantiles (i.e., at the median or below). Both

132 intergroup and intragroup differences in height development trends became more

133 pronounced with stand age. For example, red oaks exhibited a broad distribution of

134 heights, spanning $4.9 \mathrm{~m}$ and $13.1 \mathrm{~m}$ at ages 2 and 16 on protected backslopes 
135 respectively. In contrast to the broad variation within red oaks (as well as white oaks,

136 hickories, and other species), the sassafras, blackgum, maple, and dogwood species

137 groups exhibited much lower intragroup variation in heights. For example, the measured

138 dogwood heights distribution on protected backslopes spanned only $3.4 \mathrm{~m}$ and $7.6 \mathrm{~m}$ at

139 ages 2 and 16 respectively.

An Application

141 Consider the stem analysis derived height development of an example tree in Figure 4.

142 At the time of sampling (2014), this white oak (Q. alba) had attained a codominant

143 canopy position in a 19-year-old mixed-species, single-cohort stand on a protected

144 backslope in the Missouri Ozarks (Vickers et al. unpublished data). To demonstrate a

145 cross-sectional assessment, the $5^{\text {th }}$ year height $(3 \mathrm{~m})$ of a tree on a protected backslope

146 in a Missouri Ozarks clearcut is highlighted (diamond symbol) on the corresponding

147 site-class species reference chart in Figure 4. A height of $3 \mathrm{~m}$ at age 5 approximates the $14875^{\text {th }}$ quantile for white oaks on this site-class. Without any additional field measures, it

149 can be determined that the example tree was taller than about $75 \%$ of all white oaks on

150 similar sites at the same age. Further, comparing the height of this example tree to

151 other species groups via the site-class species references indicates that on similar sites

152 about $20 \%$ of red oaks, hickories, or sassafras, $40 \%$ of blackgum or dogwood, $46 \%$ of

153 maples, and about $10 \%$ of trees in the other species group would be taller at age 5 .

154 Although this tree was in a favorable canopy position at the time of sampling (age 19), a

155 longitudinal assessment suggests that before age 7, the height development of this tree 156 was not exceptional for white oaks on similar sites. Moreover, through about age 6 this 
157 tree was between the $25^{\text {th }}$ and $75^{\text {th }}$ quantiles across all species groups, including the 158 short-statured dogwood. However after age 8-10 through age 16, an extant neighbor of

159 many species had, at most, a 1\% marginal chance of being taller than this tree. A

160 nearby red oak would have had, at most, about a 15\% marginal chance of being taller

161 while neighboring white oaks or hickories had, at most, about a 5\% marginal chance.

162 Discussion

163 A clear advantage of reference chart methodology is the explicit focus on distributions 164 rather than on averages or categorical conditions. The focus on distributions provides 165 broad context for field measured heights, allowing outlier detection relative to 166 mainstream development trends for a given peer group as well as quantitative 167 assessment of an individual's stature independent of neighbors. Such assessments 168 present opportunities to refine silvicultural applications in young mixed stands (e.g., 169 precommerical thinning and crop tree release) by identifying release candidates based 170 on antecedent species-specific performance in addition to, or perhaps despite, current 171 relative stature among neighbors.

172 The focus on distributions when utilizing reference charts provides context for stand 173 reconstruction techniques and creates opportunities for more comprehensive 174 interpretations of developmental dynamics. A recognized shortcoming of stand 175 reconstruction techniques has been the inability to account for the influence of trees that 176 did not survive to be sampled. Reference charts can extend the inference obtained from 177 stand reconstruction methods by providing comparative references for longitudinal data 178 and quantitative information on temporal variation in early stand development patterns. 
179 A suite of reference charts creates a valuable framework for comparisons of

180 intraspecific and interspecific development by examining the expected strength and 181 duration of competition among species based on the degree of overlap and timing of 182 divergences in their distributions. Such comparative examinations would suggest, based 183 on mainstream trends, if and when one species might be expected to outpace another. 184 For example, the species with more narrow height distributions in (Figs. 2 and 3) are 185 186 rarely (sassafras, blackgum, maples) or never (dogwood) components of the overstory canopy in mature forests of the Missouri Ozarks (Burns and Honkala 1990, Johnson et al. 2009), but given the considerable overlap in early height distributions they are clearly capable of being a source of competition in young stands.

Interpretation of development patterns should be done with some caution. The quantile lines reflect the height distribution of a peer group at a given point in time, rather than the distribution of growth. This seemingly minor distinction in stature vs. growth can have profound inferential consequences and has led to separate reference chart categories for stature and growth in the medical literature (Cole 1994, Wei et al. 2006). To strengthen this distinction, recall the height development pattern of the white oak used in the application example. When the development pattern of this tree was plotted against the white oak site-class-species reference chart (Fig. 4), it appeared to exhibit extraordinary growth between stand ages $7-11$, ultimately resulting in a much higher quantile assessment. However, this interpretation may be misleading as it cannot be determined from our stature based charts if the growth displayed between ages 7-11 is atypical of what might be expected from other white oaks with a similar stature at the start of their $7^{\text {th }}$ growing season. It should also be expected that an individual tree may 
202 cross quantiles as it develops. This is common in human growth assessments (Cole 203 1994), and similar tree growth dynamics have been reported over the course of stand 204 development (Dahms 1963, Rennolls 1978).

205 Our reference charts were constructed with data from open populations rather than a 206 finite number of individuals, and naturally occurring population changes (e.g., stochastic 207 disturbances, mortality, late germinants) can influence the height distributions. Our 208 reference charts, like many of the most widely used anthropometric reference charts 209 (Kuczmarski et al. 2002, de Onis et al. 2007), were developed with multiple datasets 210 pieced together and analyzed cross-sectionally. Thus, latent differences in the 211 combined datasets, as well as any other deficiencies in the data used to construct the 212 reference charts may influence both parameter and quantile estimates.

213 While Boulfroy et al. (2012) present a related application of reference values for 214 diameter increment of Thuja occidentalis L., we note that quantiles reported from 215 reference chart methodology conceptually differ from most others previously utilized for 216 forestry applications (e.g., Stage 1973, Bohora and Cao 2014). This is due to 217 differences in the peer groups that the respective evaluations used for inference.

218 Generally, the peer groups used by reference chart methods will represent a broader 219 population that is derived from many individuals that share some common characteristic 220 across multiple stands (e.g., site class and/or species). In contrast, neighborhood or 221 stand-level peer groups draw inference from a more restricted population and have no 222 replication within a neighborhood or stand. Thus, the generality of that information will 223 be a function of inter-neighborhood or inter-stand variance. This is not to imply that 224 localized inference is invalid or subsidiary to the reference chart methodology. Both size 
225 and relative stature can influence growth in developing stands (Assmann 1970, Oliver 226 and Larson 1996, Weiner 1990). Accordingly, combining reference chart quantiles with

227 localized stature hierarchies may yield improved predictions of growth and mortality. We

228 suggest that this is an area worth exploring as it may offer insight into the relative 229 importance of individual growth and neighborhood competition on developmental 230 processes.

231 Acknowledgements

232 The lead author is especially grateful to Scarlett, Autumn, and Hazel Vickers for 233 inspiring and sustaining this effort with serendipitous visits to the pediatrician. He thanks

234 Dr. Amanda Vickers for engaging discussions on the use of reference charts by 235 physicians and their potential for forestry applications. All authors thank the Northern 236 Research Station of the USDA Forest Service for funding assistance and the efforts of 237 numerous current and former employees, including Ivan Sander and Paul Johnson, in 238 administering studies and preserving data we were fortunate to utilize. We similarly 239 thank the Missouri Department of Conservation for funding assistance and the efforts of 240 Randy Jensen and numerous other employees in administering studies and preserving 241 data. This article was improved by helpful suggestions and statistical advice from Paul 242 L. Speckman.

\section{References}

Assmann, E. 1970. The Principles of Forest Yield Study. New York. Pergamon Press. $506 p$. 
Bohora, S.B., Cao, Q.V. 2014. Prediction of tree diameter growth using quantile regression and mixed-effects models. For. Ecol. Mgmt. 319: 62-66.

Boulfroy, E., Forget, E., Hofmeyer, P.V., Kenefic, L.S., Larouche, C., Lessard, G., Lussier, J.-M., Pinto, F., Ruel, J.-C., Weiskittel, A. 2012. Silvicultural guide for northern white-cedar (eastern white cedar). USDA For. Serv. Gen. Tech. Rep. NRS-98. 74p.

Burns, R.M., Honkala, B.H. (eds.). 1990. Silvics of North America, Volume 2, Hardwoods. USDA For. Serv. Agriculture Handbook 654. Washington, D.C. $675 p$.

Cole, T.J. 1994. Growth charts for both cross-sectional and longitudinal data. Statistics in Medicine. 13(23-24): 2477-2492.

Cole, T.J., Green, P.J. 1992. Smoothing reference centile curves: the LMS method and penalized likelihood. Statistics in Medicine. 11: 1305-1319.

Dahms, W.G. 1963. Correction for a possible bias in developing site index curves form sectioned tree data. J. For. 61: 25-27.

Delignette-Muller, M.L., Dutang, C. 2015. Fitdistrplus: An R package for fitting distributions. J. Statistical Software 64(4): 1-34.

de Onis, M., Onyango, A.W., Borghi, E., Siyam, A., Nishida, C., Siekmann, J. 2007. Development of a WHO growth reference for school-aged children and adolescents. Bull. World Health Organization 85(9): 660-667. 
Faraway, J., Marsaglia, G., Marsaglia, J., Baddeley, A. 2017. Goftest: Classical goodness-of-fit tests for univariate distributions. R package version 1.0-4. http://CRAN.R-project.org/package=goftest.

Johnson, P.S., Shifley, S.R., Rogers, R. 2009. The Ecology and Silviculture of Oaks. CABI. 600p.

Kabrick, J.M., Meinert, D., Nigh, T., Gorlinsky, B.J. 2000. Physical environment of the Missouri Ozark forest ecosystem project sites. In Shifley, Stephen R.; Brookshire, Brian L. ed. Missouri Ozark Forest Ecosystem Project: site history, soils, landforms, woody and herbaceous vegetation, down wood, and inventory methods for the landscape experiment. Gen. Tech. Rep. NC-208. St. Paul, MN: U.S. Dept. of Agriculture, Forest Service, North Central Forest Experiment Station. 41-70.

Kabrick, J.M., Zenner, E.K., Dey, D.C., Gwaze, D., Jensen, R.G. 2008. Using ecological land types to examine landscape-scale oak regeneration dynamics. For. Ecol. Mgmt. 255: 3051-3062.

Kelty, M.J., Larson, B.C., Oliver, C.D. 1992. The Ecology of Mixed-Species Forests: A Festschrift for David M. Smith. Springer. 291p.

Kuczmarski, R.J., Ogden, C.L., Guo, S.S., et al. 2002. 2000 CDC growth charts for the United States: methods and development. National Center for Health Statistics. Vital Health Stat 11(246). 
McQuilkin, R.A. 1974. Site index prediction tables for black, scarlet, and white oaks in southeastern Missouri. USDA For. Serv. Res. Pap. NC-108.

Nigh, T., Buck, C., Grabner, J., Kabrick, J., Meinert, D. 2000. Ecological Classification System for the Current River Hills Subsection. Missouri Department of Conservation Publication. Jefferson City, MO. 84 p.

Oliver, C.D., Larson, B.C. 1996. Forest Stand Dynamics. $2^{\text {nd }}$ ed. John Wiley \& Sons, Inc. New York. 520p.

Quetelet, A. 1871. Anthropometrie. Brussels. Muquardt.

R Core Team 2015. R: A language and environment for statistical computing. R Foundation for Statistical Computing, Vienna, Austria. http://www.R-project.org/.

Rennolls, K. 1978. "Top Height”; its definition and estimation. Commonw. For. Rev. 57: 215-219.

Stage, A.R. 1973. Prognosis model for stand development. Res. Pap. INT-137. United States Dept. Agriculture, Intermountain Forest and Range Experiment Station, Ogden, UT.

Ulijaszek, S.J., Johnston, F.E., Preece, M.A. 1998. The Cambridge Encyclopedia of Human Growth and Development. Cambridge University Press. 509p.

Venables, W.N., Ripley, B.D. 2002. Modern Applied Statistics with S. $4^{\text {th }}$ ed. Springer.

Vickers, L.A., Larsen, D.R., Knapp, B.O., Kabrick, J.M., Dey, D.C. 2014. The impact of overstory density on sapling height growth in the Missouri Ozarks - implications 
for interspecific differentiation during canopy recruitment. Can. J. For. Res. 44(11): 1320-1330.

Ward, J.S., Stephens, G.R. 1993. Influence of crown class and shade tolerance on individual tree development during deciduous forest succession in Connecticut, USA. For. Ecol. Mgmt. 60: 207-236.

Ward, J.S., Stephens, G.R. 1994. Crown class transition rates of maturing northern red oak (Quercus rubra L.). For. Sci. 40: 1-17.

Ward, J.S., Stephens, G.R. 1996. Influence of crown class on survival and development of Betula lenta in Connecticut, U.S.A. Can. J. For. Res. 26: 277-288.

Wei, Y., Pere, A., Koenker, R., Xuming, H. 2006. Quantile regression methods for reference growth charts. Statistics in Medicine. 25: 1369-1382.

Weiner, J. 1990. Asymmetric competition in plant populations. Trends Ecol. Evol. 5: 360-364. 
Table 1. Weibull distribution parameter estimates for the site-class based based heightage reference charts in this study. Bracketed values are bootstrapped $95 \%$ confidence intervals (2000 iterations). The Anderson-Darling test (AD) was used to evaluate goodness of fit where p-values $\leq 0.05$ suggest rejecting the hypothesis that the data follows the specified distribution.

\begin{tabular}{|c|c|c|c|c|c|}
\hline \multirow{2}{*}{$\begin{array}{l}\text { Species } \\
\text { Group }\end{array}$} & \multirow{2}{*}{ Age } & \multirow{2}{*}{$\mathrm{n}$} & \multicolumn{2}{|c|}{ Weibull parameters } & \multirow{2}{*}{$A D$} \\
\hline & & & Shape & Scale & \\
\hline \multirow{4}{*}{$\begin{array}{l}\text { exposed } \\
\text { backslopes }\end{array}$} & 2 & 336 & $\begin{array}{c}1.7717 \\
{[1.6336,1.9219]}\end{array}$ & $\begin{array}{c}1.5754 \\
{[1.4750,1.6789]}\end{array}$ & 0.7426 \\
\hline & 5 & 324 & $\begin{array}{c}2.0771 \\
{[1.9010,2.2791]}\end{array}$ & $\begin{array}{c}2.7277 \\
{[2.5850,2.28860]}\end{array}$ & 0.7676 \\
\hline & 10 & 307 & $\begin{array}{c}2.0285 \\
{[1.8661,2.2152]}\end{array}$ & $\begin{array}{c}4.3245 \\
{[4.0653,4.5754]}\end{array}$ & 0.0984 \\
\hline & 16 & 1839 & $\begin{array}{c}1.8869 \\
{[1.8201,1.9607]}\end{array}$ & $\begin{array}{c}4.6629 \\
{[4.5377,4.7889]}\end{array}$ & $<.0001$ \\
\hline \multirow{4}{*}{$\begin{array}{c}\text { protected } \\
\text { backslopes }\end{array}$} & 2 & 767 & $\begin{array}{c}1.5909 \\
{[1.5115,1.6897]}\end{array}$ & $\begin{array}{c}1.4920 \\
{[1.4235,1.5632]}\end{array}$ & 0.0228 \\
\hline & 5 & 731 & $\begin{array}{c}2.1540 \\
{[2.0316,2.2865]}\end{array}$ & $\begin{array}{c}2.5812 \\
{[2.4906,2.6757]}\end{array}$ & 0.3150 \\
\hline & 10 & 687 & $\begin{array}{c}2.1825 \\
{[2.0596,2.3184]}\end{array}$ & $\begin{array}{c}4.2253 \\
{[4.0762,4.3724]}\end{array}$ & 0.0046 \\
\hline & 16 & 1664 & $\begin{array}{c}1.8077 \\
{[1.7421,1.8787]}\end{array}$ & $\begin{array}{c}5.0237 \\
{[4.8849,5.1637]}\end{array}$ & 0.0003 \\
\hline
\end{tabular}


Table 2. Weibull distribution parameter estimates for the species based height-age reference charts for exposed backslopes in this study. Bracketed values are bootstrapped $95 \%$ confidence intervals (2000 iterations). The Anderson-Darling test (AD) was used to evaluate goodness of fit where $p$-values $\leq 0.05$ suggest rejecting that the data follows the specified distribution.

\begin{tabular}{|c|c|c|c|c|c|}
\hline \multirow{2}{*}{$\begin{array}{l}\text { Species } \\
\text { Group }\end{array}$} & \multirow{2}{*}{ Age } & \multirow{2}{*}{$\mathrm{n}$} & \multicolumn{2}{|c|}{ Weibull parameters } & \multirow{2}{*}{$A D$} \\
\hline & & & Shape & Scale & \\
\hline \multirow{4}{*}{$\begin{array}{l}\text { red } \\
\text { oaks }\end{array}$} & 2 & 79 & $\begin{array}{c}1.3645 \\
{[1.1543,1.6274]}\end{array}$ & $\begin{array}{c}1.3603 \\
{[1.1443,1.6068]}\end{array}$ & 0.5929 \\
\hline & 5 & 74 & $\begin{array}{c}1.5322 \\
{[1.2859,1.8581]}\end{array}$ & $\begin{array}{c}2.7684 \\
{[2.3542,3.2307]}\end{array}$ & 0.6560 \\
\hline & 10 & 73 & $\begin{array}{c}1.6410 \\
{[1.3815,2.0126]}\end{array}$ & $\begin{array}{c}4.6457 \\
{[3.9644,5.3729]}\end{array}$ & 0.1860 \\
\hline & 16 & 214 & $\begin{array}{c}1.9372 \\
{[1.7463,2.1583]}\end{array}$ & $\begin{array}{c}6.8135 \\
{[6.3294,7.3088]}\end{array}$ & 0.3702 \\
\hline \multirow{4}{*}{$\begin{array}{l}\text { white } \\
\text { oaks }\end{array}$} & 2 & 79 & $\begin{array}{c}1.9901 \\
{[1.6849,2.3713]}\end{array}$ & $\begin{array}{c}1.6694 \\
{[1.4760,1.8628]}\end{array}$ & 0.6122 \\
\hline & 5 & 79 & $\begin{array}{c}2.8443 \\
{[2.4161,3.4237]}\end{array}$ & $\begin{array}{c}3.2753 \\
{[3.0133,3.5705]}\end{array}$ & 0.7569 \\
\hline & 10 & 78 & $\begin{array}{c}3.0268 \\
{[2.5397,3.6208]}\end{array}$ & $\begin{array}{c}5.3653 \\
{[4.9445,5.8081]}\end{array}$ & 0.1475 \\
\hline & 16 & 522 & $\begin{array}{c}1.7298 \\
{[1.6279,1.8518]}\end{array}$ & $\begin{array}{c}4.3494 \\
{[4.1270,4,5728]}\end{array}$ & 0.0001 \\
\hline \multirow{4}{*}{ hickories } & 2 & 58 & $\begin{array}{c}1.8134 \\
{[1.4940,2.2484]}\end{array}$ & $\begin{array}{c}1.2696 \\
{[1.0807,1.4605]}\end{array}$ & 0.5690 \\
\hline & 5 & 57 & $\begin{array}{c}2.5988 \\
{[2.1581,3.2373]}\end{array}$ & $\begin{array}{c}2.2189 \\
{[1.9923,2.4416]}\end{array}$ & 0.7246 \\
\hline & 10 & 58 & $\begin{array}{c}2.2867 \\
{[1.8936,2.8180]}\end{array}$ & $\begin{array}{c}3.5402 \\
{[3.1100,3.9639]}\end{array}$ & 0.3305 \\
\hline & 16 & 205 & $\begin{array}{c}2.0123 \\
{[1.8041,2.2422]}\end{array}$ & $\begin{array}{c}4.8651 \\
{[4.5114,5.2301]}\end{array}$ & 0.1605 \\
\hline \multirow{4}{*}{ sassafras } & 2 & 39 & $\begin{array}{c}1.9409 \\
{[1.5473,2.5244]}\end{array}$ & $\begin{array}{c}1.6686 \\
{[1.3891,1.9702]}\end{array}$ & 0.5013 \\
\hline & 5 & 35 & $\begin{array}{c}2.4406 \\
{[1.9193,3.2265]}\end{array}$ & $\begin{array}{c}2.5673 \\
{[2.1813,2.9356]}\end{array}$ & 0.9640 \\
\hline & 10 & 29 & $\begin{array}{c}2.1002 \\
{[1.5813,2.8900]}\end{array}$ & $\begin{array}{c}3.3248 \\
{[2.7234,3.9576]}\end{array}$ & 0.4807 \\
\hline & 16 & 136 & $\begin{array}{c}3.5347 \\
{[3.0978,4.0634]}\end{array}$ & $\begin{array}{c}5.6207 \\
{[5.3353,5.9088]}\end{array}$ & 0.6287 \\
\hline \multirow{4}{*}{ blackgum } & 2 & 26 & $\begin{array}{c}2.8292 \\
{[2.0963,4.0078]}\end{array}$ & $\begin{array}{c}1.9500 \\
{[1.6750,2.2469]}\end{array}$ & 0.8227 \\
\hline & 5 & 26 & $\begin{array}{c}3.4368 \\
{[2.5637,4.7823]}\end{array}$ & $\begin{array}{c}2.6670 \\
{[2.3440,2.9816]}\end{array}$ & 0.9283 \\
\hline & 10 & 26 & $\begin{array}{c}3.4319 \\
{[2.5649,4.6539]}\end{array}$ & $\begin{array}{c}3.6531 \\
{[3.2109,4.1094]}\end{array}$ & 0.9504 \\
\hline & 16 & 115 & $\begin{array}{c}2.8113 \\
{[2.4250,3.2528]}\end{array}$ & $\begin{array}{c}4.1355 \\
{[3.85544,4.4321]}\end{array}$ & 0.7108 \\
\hline \multirow{4}{*}{ dogwood } & 2 & 27 & $\begin{array}{c}2.9456 \\
{[2.2338,4.1274]}\end{array}$ & $\begin{array}{c}2.1596 \\
{[1.8600,2.4658]}\end{array}$ & 0.9931 \\
\hline & 5 & 26 & $\begin{array}{c}2.8399 \\
{[2.1311,4.0168]}\end{array}$ & $\begin{array}{c}2.3404 \\
{[1.9776,2.7028]}\end{array}$ & 0.6724 \\
\hline & 10 & 17 & $\begin{array}{c}2.7853 \\
{[1.9255,4.2239]}\end{array}$ & $\begin{array}{c}3.4969 \\
{[2.8707,4.1852]}\end{array}$ & 0.7596 \\
\hline & 16 & 214 & $\begin{array}{c}2.9359 \\
{[2.6631,3.2968]}\end{array}$ & $\begin{array}{c}3.6804 \\
{[3.5000,3.8610]}\end{array}$ & 0.4657 \\
\hline \multirow{4}{*}{ maples } & 2 & 8 & $\begin{array}{c}2.3536 \\
{[1.3921,4.8552]}\end{array}$ & $\begin{array}{c}1.6283 \\
{[1.0787,2.2167]}\end{array}$ & 0.4671 \\
\hline & 5 & 8 & $\begin{array}{c}2.3727 \\
{[1.3912,4.8264]}\end{array}$ & $\begin{array}{c}2.9437 \\
{[1.9966,4.0299]}\end{array}$ & 0.9526 \\
\hline & 10 & 8 & $\begin{array}{c}2.5941 \\
{[1.5547,5.3275]}\end{array}$ & $\begin{array}{c}4.5223 \\
{[3.0935,5.9955]}\end{array}$ & 0.9581 \\
\hline & 16 & 130 & $\begin{array}{c}2.1484 \\
{[1.8935,2.4674]}\end{array}$ & $\begin{array}{c}3.8051 \\
{[3.4828,4.1376]}\end{array}$ & 0.0776 \\
\hline \multirow{4}{*}{$\begin{array}{l}\text { other } \\
\text { species }\end{array}$} & 2 & 20 & $\begin{array}{c}2.0986 \\
{[1,5222,3.1211]}\end{array}$ & $\begin{array}{c}1.3001 \\
{[1.0027,1.6097]}\end{array}$ & 0.7614 \\
\hline & 5 & 19 & $\begin{array}{c}2.7475 \\
{[1.9698,4.0641]}\end{array}$ & $\begin{array}{c}2.2262 \\
{[1.8276,2.6370]}\end{array}$ & 0.8522 \\
\hline & 10 & 18 & $\begin{array}{c}2.4285 \\
{[1.7243,3.6798]}\end{array}$ & $\begin{array}{c}3.5935 \\
{[2.8698,4.4057]}\end{array}$ & 0.8280 \\
\hline & 16 & 302 & $\begin{array}{c}2.0657 \\
{[1.8972,2.2581]}\end{array}$ & $\begin{array}{c}4.2625 \\
{[4.0181,4.5055]}\end{array}$ & 0.2388 \\
\hline
\end{tabular}


Table 3. Weibull distribution parameter estimates for the species based height-age reference charts on protected backslopes used in this study. Bracketed values are bootstrapped $95 \%$ confidence intervals (2000 iterations). The Anderson-Darling test $(A D)$ was used to evaluate goodness of fit where $p$-values $\leq 0.05$ suggest rejecting that the data follows the specified distribution.

\begin{tabular}{|c|c|c|c|c|c|}
\hline \multirow{2}{*}{$\begin{array}{l}\text { Species } \\
\text { Group }\end{array}$} & \multirow{2}{*}{ Age } & \multirow{2}{*}{$\mathrm{n}$} & \multicolumn{2}{|c|}{ Weibull parameters } & \multirow{2}{*}{$A D$} \\
\hline & & & Shape & Scale & \\
\hline \multirow{4}{*}{$\begin{array}{l}\text { red } \\
\text { oaks }\end{array}$} & 2 & 209 & $\begin{array}{c}1.5980 \\
{[1.4398,1.7814]}\end{array}$ & $\begin{array}{c}1.2733 \\
1.1658,1.3910]\end{array}$ & 0.3955 \\
\hline & 5 & 200 & $\begin{array}{c}2.0828 \\
{[1.8755,2.3186]}\end{array}$ & $\begin{array}{c}2.4012 \\
{[2.2318,2.5715]}\end{array}$ & 0.3158 \\
\hline & 10 & 188 & $\begin{array}{c}2.1323 \\
{[1.9088,2.3821]}\end{array}$ & $\begin{array}{c}4.5675 \\
{[4.2546,4.9033]}\end{array}$ & 0.0870 \\
\hline & 16 & 106 & $\begin{array}{c}2.0334 \\
{[1.7678,2.3986]}\end{array}$ & $\begin{array}{c}7.5384 \\
{[6.8656,8.2946]}\end{array}$ & 0.1104 \\
\hline \multirow{4}{*}{$\begin{array}{l}\text { white } \\
\text { oaks }\end{array}$} & 2 & 145 & {$[1.2206,1.5718]$} & $\begin{array}{c}1.3764 \\
{[1.2104,1.5467]}\end{array}$ & 0.2131 \\
\hline & 5 & 142 & $\begin{array}{c}1.9790 \\
{[1.7468,2.2638]}\end{array}$ & $\begin{array}{c}2.5916 \\
{[2.3552,2.8175]}\end{array}$ & 0.2468 \\
\hline & 10 & 141 & $\begin{array}{c}2.0103 \\
{[1.7797,2.2777]}\end{array}$ & $\begin{array}{c}4.4001 \\
{[4.0258,4.7930]}\end{array}$ & 0.0395 \\
\hline & 16 & 204 & $\begin{array}{c}1.3897 \\
{[1.2524,1.5531]}\end{array}$ & $\begin{array}{c}4.9691 \\
{[4.4868,5.5134]}\end{array}$ & 0.0022 \\
\hline \multirow{4}{*}{ hickories } & 2 & 149 & $\begin{array}{c}1.4285 \\
{[1.2657,1.6247]}\end{array}$ & $\begin{array}{c}1.3983 \\
{[1.2368,1.5642]}\end{array}$ & 0.0970 \\
\hline & 5 & 151 & $\begin{array}{c}2.1972 \\
{[1.9466,2.4995]}\end{array}$ & $\begin{array}{c}2.4495 \\
{[2.2655,2.6389]}\end{array}$ & 0.4384 \\
\hline & 10 & 148 & $\begin{array}{c}2.7111 \\
{[2.3990,3.0825]}\end{array}$ & $\begin{array}{c}4.0356 \\
{[3.7939,4.2887]}\end{array}$ & 0.6502 \\
\hline & 16 & 173 & $\begin{array}{c}1.7836 \\
{[1.5839,2.0009}\end{array}$ & $\begin{array}{c}4.5505 \\
{[4.1476,4.9608]}\end{array}$ & 0.2467 \\
\hline \multirow{4}{*}{ sassafras } & 2 & 77 & $\begin{array}{c}2.0858 \\
{[1.7724,2.4964]}\end{array}$ & $\begin{array}{c}1.6240 \\
{[1.4459,1.8101]}\end{array}$ & 0.3572 \\
\hline & 5 & 61 & $\begin{array}{c}2.3446 \\
{[1.9328,2.8933]}\end{array}$ & $\begin{array}{c}2.4676 \\
{[2.1924,2.7549]}\end{array}$ & 0.9576 \\
\hline & 10 & 47 & $\begin{array}{c}1.6265 \\
{[1.3158,2.0764]}\end{array}$ & $\begin{array}{c}3.0997 \\
{[2.5467,3.6927]}\end{array}$ & 0.2360 \\
\hline & 16 & 170 & $\begin{array}{c}3.6604 \\
{[3.2544,4.1296]}\end{array}$ & $\begin{array}{c}7.1522 \\
{[6.8395,7.4667]}\end{array}$ & 0.6960 \\
\hline \multirow{4}{*}{ blackgum } & 2 & 60 & $\begin{array}{c}1.9969 \\
{[1.6417,2.4988]}\end{array}$ & $\begin{array}{c}1.9619 \\
{[1.7012,2.2406]}\end{array}$ & 0.4493 \\
\hline & 5 & 57 & $\begin{array}{c}2.4996 \\
{[2.0654,3.0776]}\end{array}$ & $\begin{array}{c}3.0371 \\
{[2.6970,3.3825]}\end{array}$ & 0.8936 \\
\hline & 10 & 51 & $\begin{array}{c}2.2757 \\
{[1.8518,2.9061]}\end{array}$ & $\begin{array}{c}4.3899 \\
{[3.8237,4.9744]}\end{array}$ & 0.4349 \\
\hline & 16 & 81 & $\begin{array}{c}2.3465 \\
{[1.9893,2.8052]}\end{array}$ & $\begin{array}{c}5.2334 \\
{[4.7246,5.7739]}\end{array}$ & 0.9879 \\
\hline \multirow{4}{*}{ dogwood } & 2 & 62 & $\begin{array}{c}2.8471 \\
{[2.3620,3.5346]}\end{array}$ & $\begin{array}{c}1.9975 \\
{[1.8157,2.1862]}\end{array}$ & 0.8348 \\
\hline & 5 & 56 & $\begin{array}{c}4.7364 \\
{[3.9136,5.8354]}\end{array}$ & $\begin{array}{c}2.9855 \\
{[2.8135,3.1649]}\end{array}$ & 0.8167 \\
\hline & 10 & 53 & $\begin{array}{c}4.4983 \\
{[3.6978,5.6395]}\end{array}$ & $\begin{array}{c}4.1785 \\
{[3.9170,4.4513]}\end{array}$ & 0.5624 \\
\hline & 16 & 246 & $\begin{array}{c}2.8455 \\
{[2.5848,3.1466]}\end{array}$ & $\begin{array}{c}3.8783 \\
{[3.6982,4.0564]}\end{array}$ & 0.4731 \\
\hline \multirow{4}{*}{ maples } & 2 & 19 & $\begin{array}{c}1.5688 \\
{[1.1096,2.3780]}\end{array}$ & $\begin{array}{c}1.8849 \\
{[1.3482,2.5261]}\end{array}$ & 0.8294 \\
\hline & 5 & 19 & $\begin{array}{c}1.7321 \\
{[1.2311,2.6332]}\end{array}$ & $\begin{array}{c}3.4787 \\
{[2.5572,4.5571]}\end{array}$ & 0.9279 \\
\hline & 10 & 18 & $\begin{array}{c}2.3087 \\
{[1.6513,3.5091]}\end{array}$ & $\begin{array}{c}4.9485 \\
{[3.9020,6.1303]}\end{array}$ & 0.9188 \\
\hline & 16 & 388 & $\begin{array}{c}1.7884 \\
{[1.6534,1.9362}\end{array}$ & $\begin{array}{c}4.2140 \\
{[3.9755,4.4703]}\end{array}$ & 0.0048 \\
\hline \multirow{4}{*}{$\begin{array}{l}\text { other } \\
\text { species }\end{array}$} & 2 & 46 & {$[1.7557,2.7295]$} & $\begin{array}{c}1.4063 \\
{[1.2062,1.6094]}\end{array}$ & 0.6912 \\
\hline & 5 & 45 & $\begin{array}{c}3.2356 \\
{[2.5801,4.1159]}\end{array}$ & $\begin{array}{c}2.3111 \\
{[2.0837,2.5508]}\end{array}$ & 0.8569 \\
\hline & 10 & 41 & $\begin{array}{c}2.4435 \\
{[1.9364,3.1307]}\end{array}$ & $\begin{array}{c}3.3813 \\
{[2.9301,3.8209]}\end{array}$ & 0.8191 \\
\hline & 16 & 296 & $\begin{array}{c}2.0285 \\
{[1.8485,2.2277]}\end{array}$ & $\begin{array}{c}4.9351 \\
{[4.6442,5.2191]}\end{array}$ & 0.9353 \\
\hline
\end{tabular}


1 Figure Captions

2 Figure 1. Site-class based height-age reference charts for mixed stands following a

3 clearcut (residual basal area $\leq 5 \mathrm{~m}^{2} \cdot \mathrm{ha}^{-1}$ ) on exposed or protected backslopes in the

4 Missouri Ozarks. Measurements for all woody species encountered (see text) are

5 included.

6 Figure 2. Site-class species based height-age reference charts for mixed stands

7 following a clearcut (residual basal area $\leq 5 \mathrm{~m}^{2} \cdot \mathrm{ha}^{-1}$ ) on exposed backslopes in the

8 Missouri Ozarks. See text for species group definitions.

9 Figure 3. Site-class -species based height-age reference charts for mixed stands

10 following a clearcut (residual basal area $\leq 5 \mathrm{~m}^{2} \cdot \mathrm{ha}^{-1}$ ) on protected backslopes in the

11 Missouri Ozarks. See text for species group definitions.

12 Figure 4. Application of site-class-species reference charts for assessment of height. A

13 stem analysis derived height development pattern from a 19 year old codominant white

14 oak (Quercus alba) on a similar site (protected backslope) in the Missouri Ozarks is

15 plotted to demonstrate a longitudinal assessment. To demonstrate a cross-sectional

16 assessment, the $5^{\text {th }}$ year height of the example tree is highlighted (diamond symbol). 

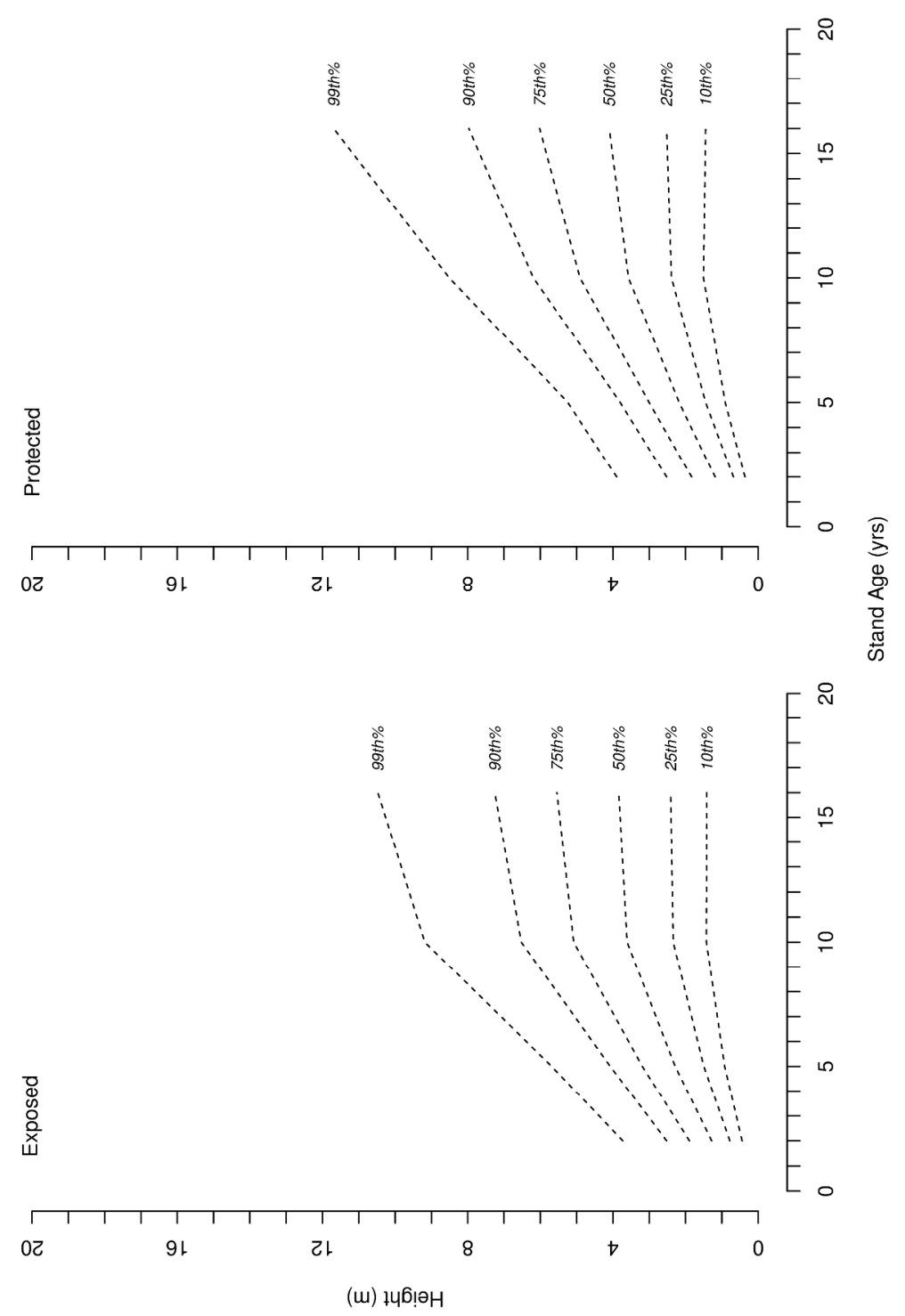

Figure 1. Site-class based height-age reference charts for mixed stands following a clearcut (residual basal area $\leq 5 \mathrm{~m}^{2} \cdot \mathrm{ha}^{-1}$ ) on exposed or protected backslopes in the Missouri Ozarks. Measurements for all woody species encountered (see text) are included.

$279 \times 361 \mathrm{~mm}(300 \times 300 \mathrm{DPI})$ 

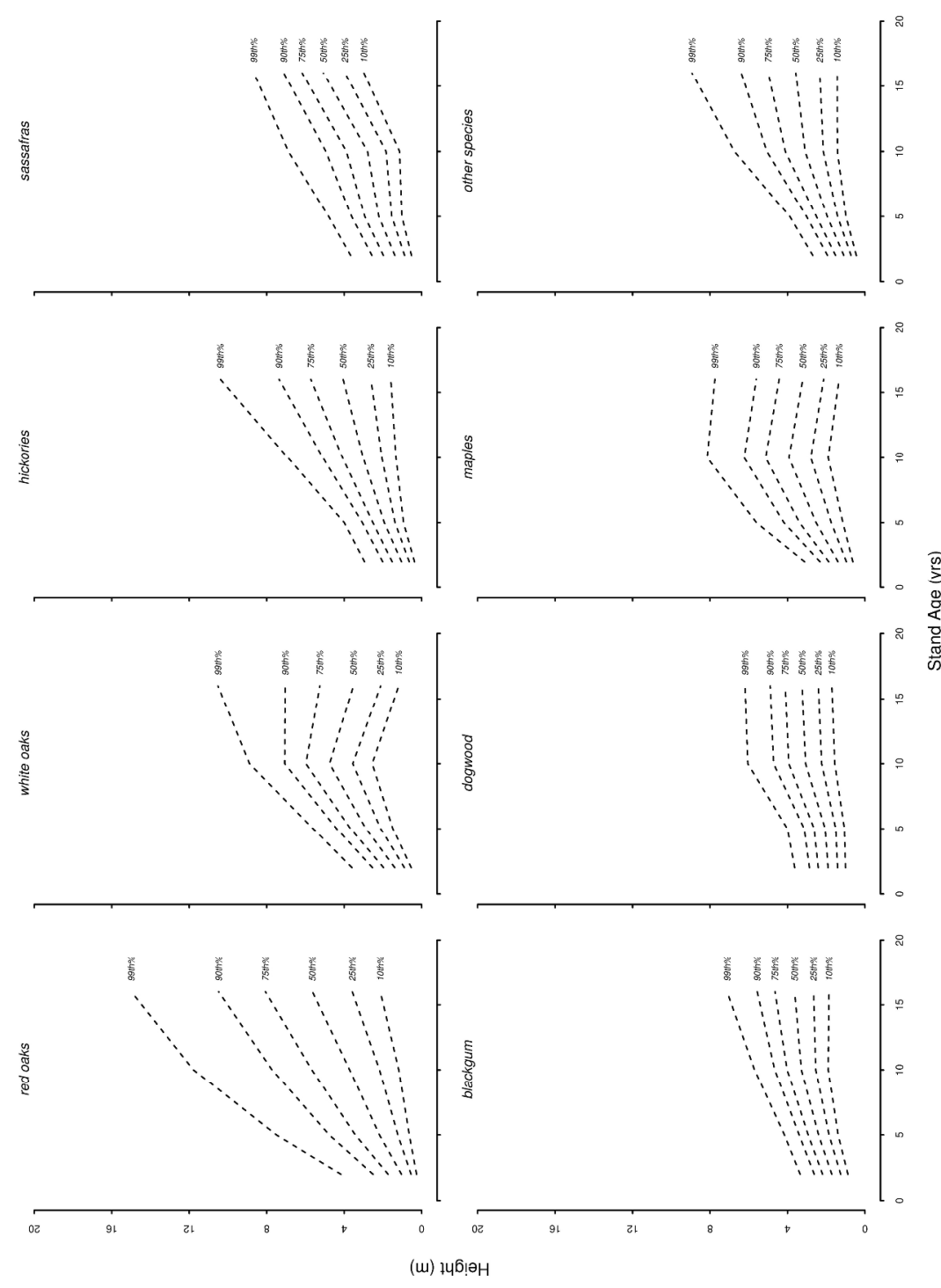

Figure 2. Site-class-species based height-age reference charts for mixed stands following a clearcut (residual basal area $\leq 5 \mathrm{~m} 2 \cdot \mathrm{ha}-1$ ) on exposed backslopes in the Missouri Ozarks. See text for species group definitions.

$279 \times 361 \mathrm{~mm}(300 \times 300 \mathrm{DPI})$ 

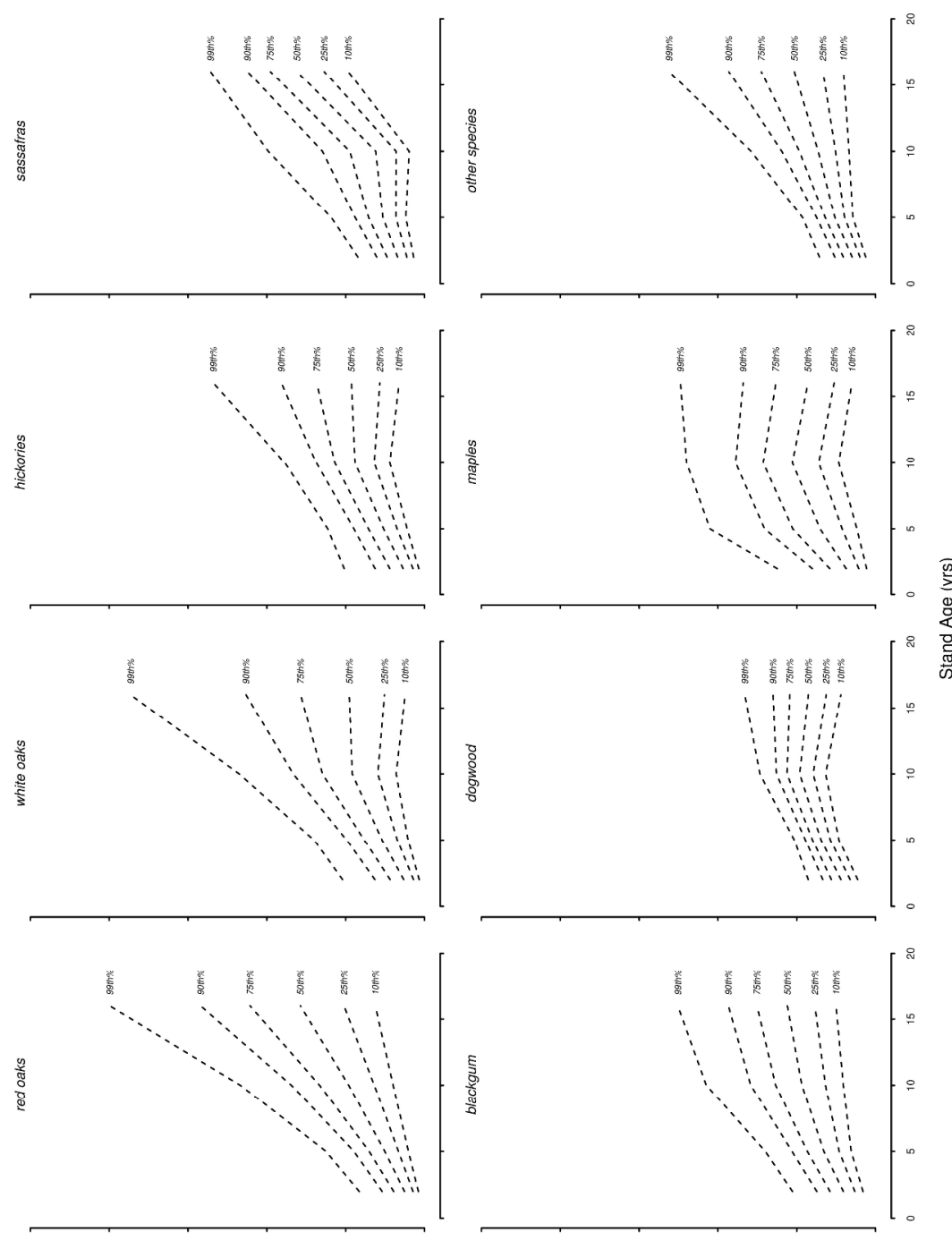

(w) $1466 !$

Figure 3. Site-class-species based height-age reference charts for mixed stands following a clearcut (residual basal area $\leq 5 \mathrm{~m} 2 \cdot$ ha-1) on protected backslopes in the Missouri Ozarks. See text for species group definitions.

$279 \times 361 \mathrm{~mm}(300 \times 300 \mathrm{DPI})$ 

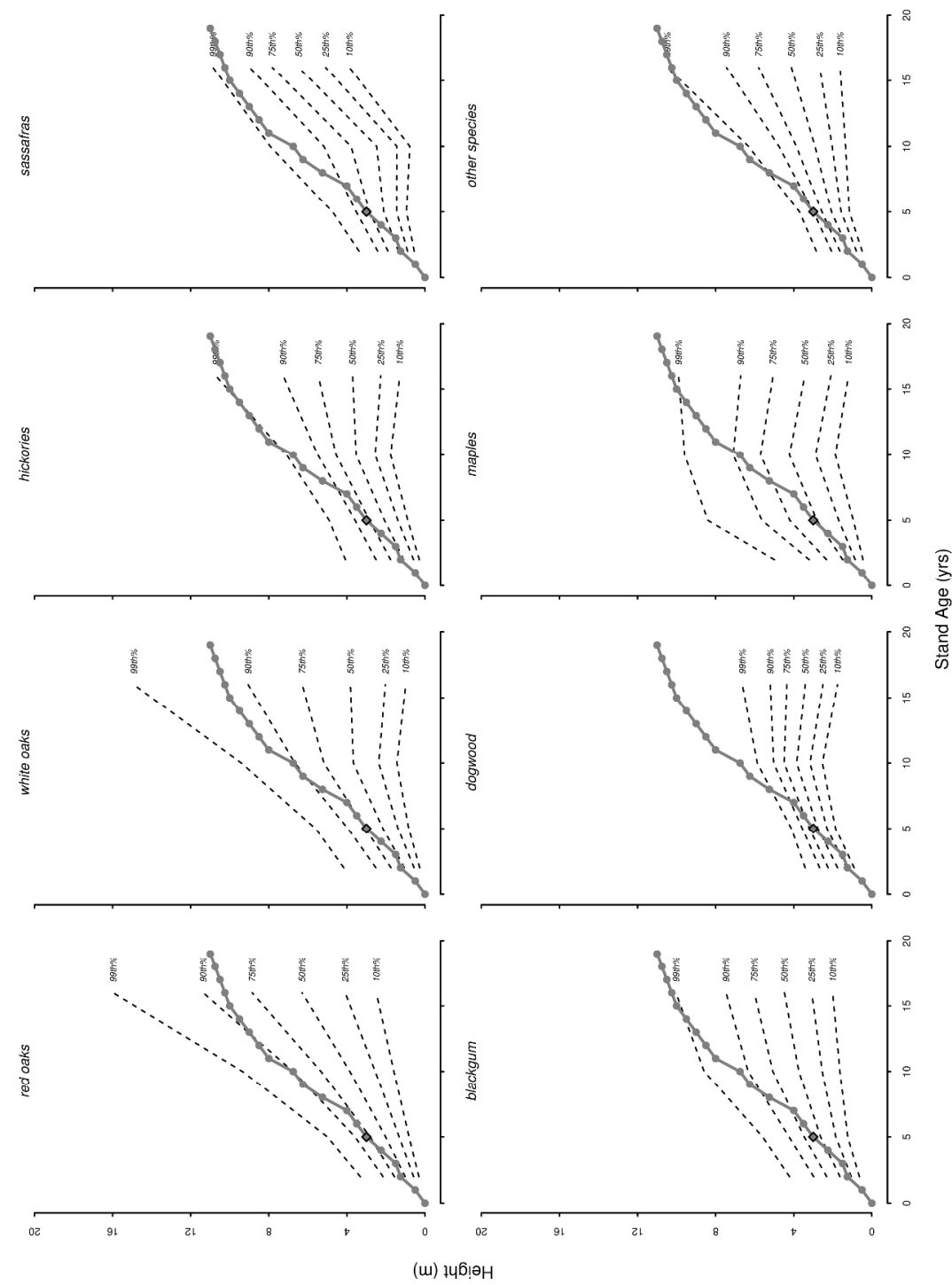

Figure 4. Application of site-class-species reference charts for assessment of height. A stem analysis derived height development pattern from a 19 year old codominant white oak (Quercus alba) on a similar site (protected backslope) in the Missouri Ozarks is plotted to demonstrate a longitudinal assessment. To demonstrate a cross-sectional assessment, the 5th year height of the example tree is highlighted (diamond symbol).

$279 \times 361 \mathrm{~mm}(300 \times 300 \mathrm{DPI})$ 